\title{
FINANCIAL EQUILIBRIUM AND RISK AVERSION IN FRENCH WORKERS' COOPERATIVES
}

\author{
by \\ Jacques DEFOURNY \\ University of Liege, Department of Economics
}

\section{Introduction}

The first developments of the economic theory of self-management concerned a firm renting all its productive capital and paying a fixed return for it. Afterwards, though, many authors considered a situation where the workers themselves, and sometimes other partners in the firm, own the capital. The second hypothesis, needless to say, corresponds much better to the reality of most workers' cooperatives. But then a question arises : what means should be used to finance the workers' acquisition of assets needed for their production?

Along those lines, R.A. Mc Cain (1977) for example, stresses the limits of having recourse to a loan because of the "growing risk principle ${ }^{1}$. For their part, E. Schlicht, C.C. von Weizsacker (1977) and B. Gui (1985) insist on the necessity for workers to individually own a certain part of the common stock in order to be able to call on external funding (such as bonds or non-voting capital shares) and to convince their potential partners of their commitments to the latter's objectives. But these rather general considerations do not provide any

1 According to this principle, the cost of loans at fixed rates is an increasing function of the importance of these loans thus obtained vis-à-vis the equity, since the creditor participates to the growing risk of the firm's insolvency but has no right to participate in possible additional profits. 
information about the desirable proportions of the different means of financing. As J.P. Bonin and L. Putterman (1987, p. 65) pointed out : *the theoretical literature has made no advance over the general finance literature in providing either a positive or a normative theory of the debt-equity ration. We can therefore expect the main criteria used in a classical approach to financial management to work for workers' cooperatives as well. In particular, it should be possible to compare workers' cooperatives and capitalist firms on a financial equilibrium basis, that is, the equilibrium between the liquidity of assets and the repayability of debts. It is what we shall try to do in the first part of this paper on the basis of data for workers' cooperatives (SCOPs) and capitalist firms in France.

In fact, the theory about the financing of a self-managed firm mostly dealt with the problem of underinvestment, that is, property rights being dissolved into collective investment does not encourage the internal accumulation of capital' Some authors also discussed the impossibility for worker-members to diversify the risk linked to common stock ownership and what consequences such a situation could have when combined with a probable aversion to risk ${ }^{3}$. Underinvestment perverse effects of collective self-financing have inspired many empirical studies, but the question of risk has practically never been considered from that angle. That is why we would like to clear somehow the air and, therefore, to propose a comparative approach to the financial risk in SCOPs and their capitalist counterparts. This will be discussed in the second half of this study.

The data we will use have been extracted from annual accounts of about 330 SCOPs for the year 1979. These SCOPs belong to fourteen different industries. As to capitalist firms in the same activities, we have computed sectoral averages for the same year, on the basis of sectoral aggregate accounts that are built by INSEE 4 each year and that are quite similar to those we have for individual SCOPs ${ }^{3}$. In every sector, we thus have an agverage firm» which will be taken as a

2 See M. Uvalic (1986) for a survey of this literature.

3 J.E. Meade (1972) and J. Drèze, (1976) among the first.

4 National Institute of Statistic and Economic Studies.

5 See our doctoral dissertation (1987) for a detailed presentation of these data on cooperative as well as capitalist firms. The whole data set from which they are taken covers the period 1970-1979. It has already been exploited for a comparative study of SCOPs' economic performance on the basis of financial ratios (Defourny, 1990) as well as for an efficiency analysis through estimated production frontiers (Defourny, 1988). 
representative of capitalist firms. Finally, let us note that, given these average capitalist firms, we have also built «average SCOPs» in each sector in order to, have the same kind of firms on both sides of our comparative analysis that will mainly rely on traditional financial ratios.

\section{Financial equilibrium}

No firm, whether a cooperative or a capitalist one, can avoid a few fundamental constraints such as the preservation of an equilibrium between the liquidity of assets and the repayability of debts. According to the traditional rule of financial equilibrium, the assets must always be financed by money staying at the disposal of a firm for a period at least equal to the assets' duration. Thus, it would not be reasonable for a firm to cover with a three-month loan, equipment for which initial investment would only be written off over 5 or 6 years. But it is no better for a firm to have all its circulating assets financed by fixed capital. This would mean that the firm would sometimes dispose of excessive and useless liquidities. Hence equilibrium can only be reached if there is a permanent confrontation between the firm's resources and their use but the balance sheet can only show this equilibrium at a given moment.

It should also be noted that this financial equilibrium cannot be defined objectively for all companies. Studying firms of the same type will undoubtedly make comparison easier. We shall see, though, that, in order to analyse conditions that preserve equilibrium, we have to take into account the specificities of some markets in which the firms operate as well as their relationships with customers, banks, suppliers, etc.

Finally, we would like to point out that the ratios, in this case, will be used to refine an analysis mostly based on the classical comparison of the respective amounts of net working capital and working capital requirement for SCOPs on the one hand and for capitalist companies on the other.

\subsection{Net working capital}

The net working capital represents the difference between fixed capital (equity and long term liabilities) and fixed assets. To calculate it, we subtracted the net fixed assets from the equity to which must be added middle-term or long-term debts and loans replacing equity 
("fonds en relais de fonds propresw) for SCOPs ${ }^{6}$.

The results of this operation are shown in Table 1 (col. 5-6) and we can see that they are all positive. In this case, the net working capital represents what $P$. Conso (1981) describes as athat part of the capital whose degree of repayability is rather low and which is used to finance these elements of assets whose degree of liquidity is rather high i.e. the circulating assets? In that sense, it expresses the safety margin that the firms have to finance their operating cycle.

Although Table 1 also gives an idea of the average size of SCOPs and their capitalist counterparts for each sector (with the average number of workers), it is not easy to compare both types of companies on the basis of the net working capital's absolute magnitude. That is why we also expressed the net working capital in relative terms, dividing the fixed capital by the net fixed assets (ratio R1). This is, indeed, the traditional efinancial equilibrium ration, whose value must obviously be greater than 1 to show the existence of positive net working capital.

When we look at the results obtained with that ratio, we see that it is, in most cases, greater on the cooperative side. Does this mean that SCOPs more often reach financial equilibrium. This is not necessarily the case. Despite its name, representing a very contested approach, this ratio is not significant in itself. In fact, it is believed more and more that net working capital must be compared with another financial indicator that we shall now calculate : the short-term financing requirement often called working capital requirement.

\subsection{Working capital requirement}

When the working capital requirement is positive, it represents that part of cyclical requirements (i.e. directly linked to the operating cycle) that is not covered by cyclical resources. Although these are constantly being renewed, they do not usually cover all the financial requirements generated by the operating cycle. Thus, there is a balance that has to be taken in charge by the firm and, since this

6 We excluded, though, from the SCOPs' fixed capital the part of loans replacing equity that is to be repaid in no more than one year. The approach chosen to calculate this part is shown in detail in the debt study (section 2).

7 A negative net working capital would mean that a part of the fixed assets is financed by short-term debts. 


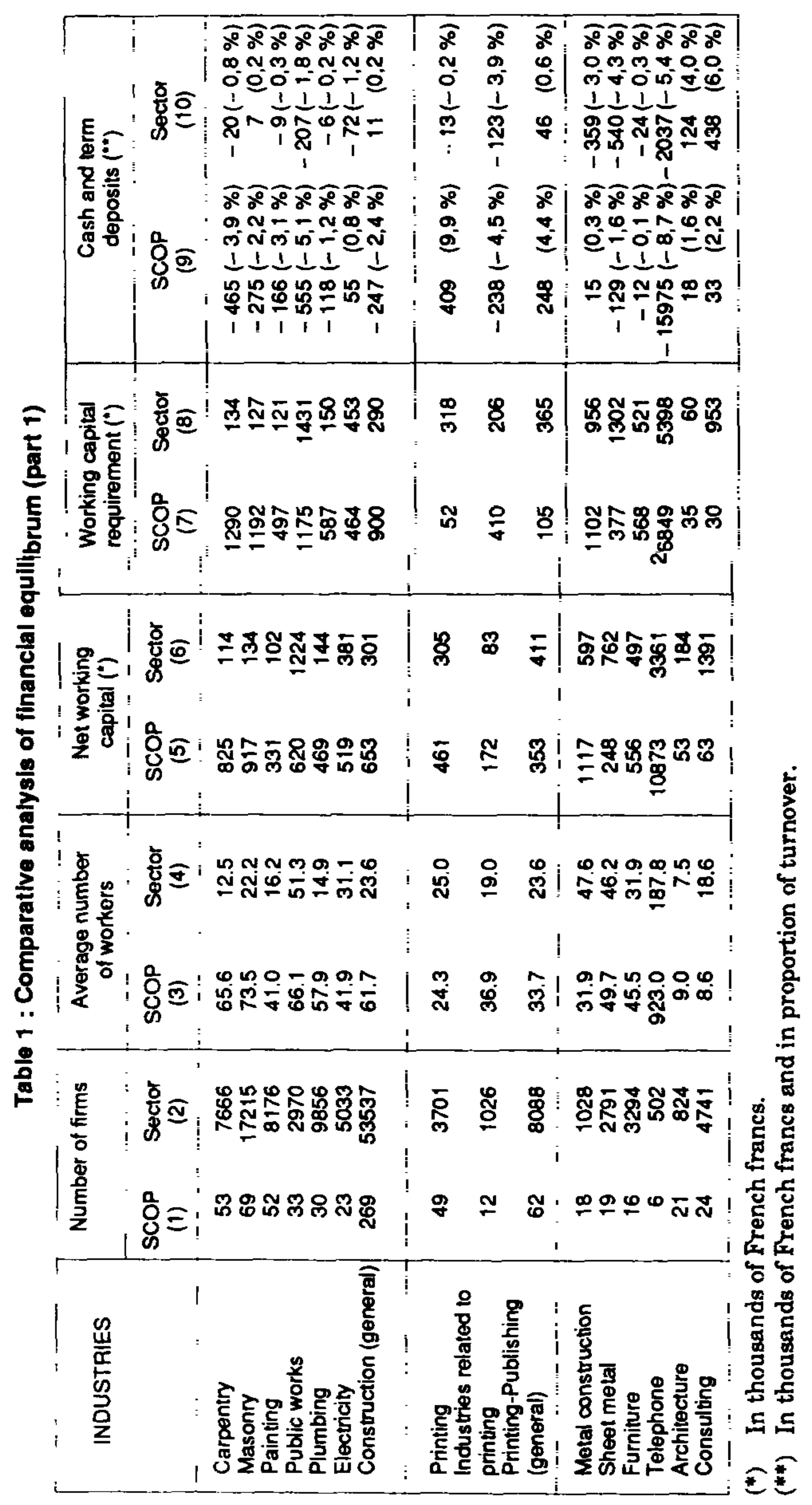




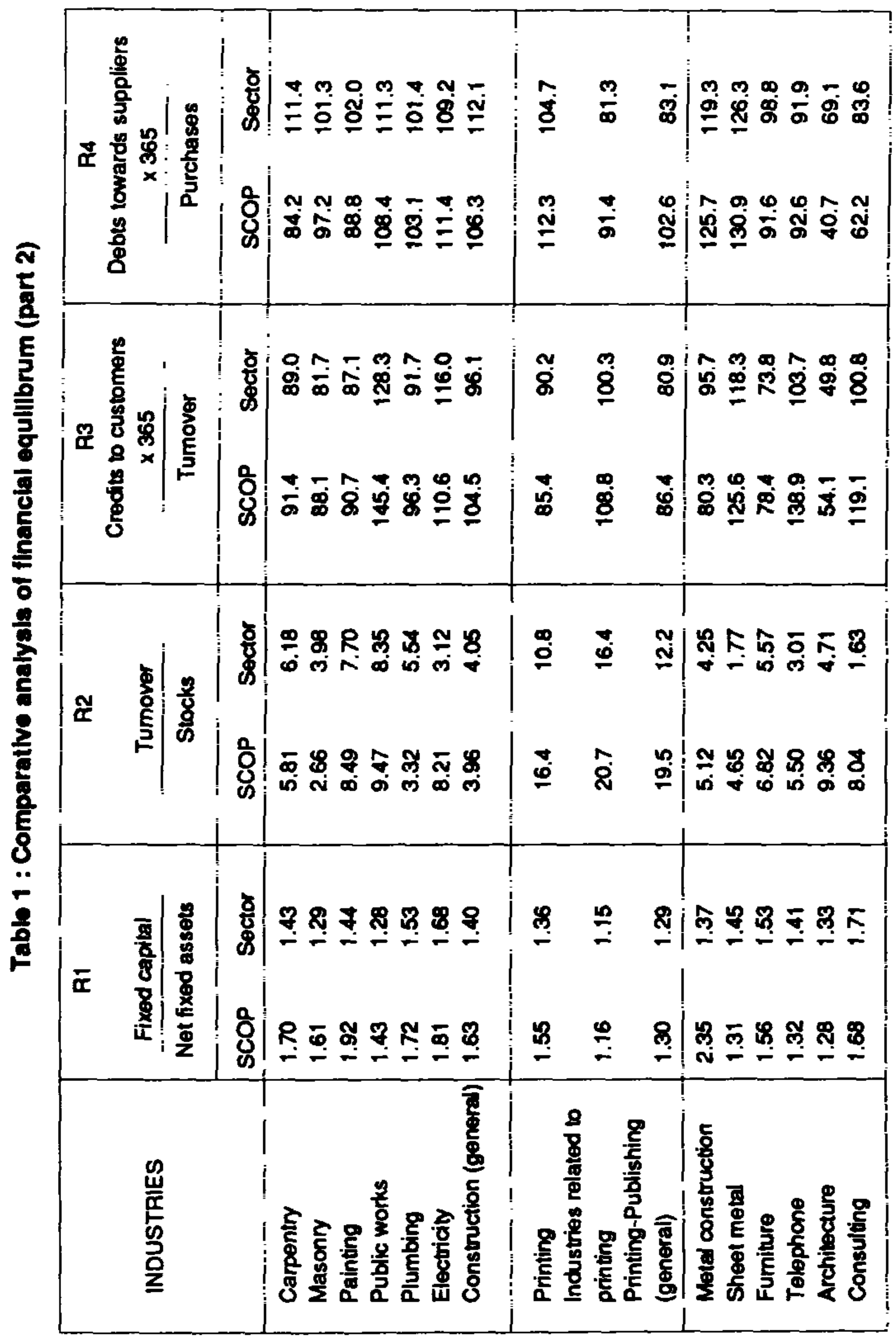


balance is permanent, the firm finances it primarily with long-term resources, i.e. its net working capital.

Although the working capital requirement is explicitly calculated in the files of the "Confederation generale des SCOPs" which separates operating cycle resources, from their uses this is not true of the INSEE's balance sheets in which sections concerning circulating assets and short-term debts also cover transactions that are not really linked to the operating cycle. ${ }^{8}$

Hence, to keep our results as comparable as possible, we preferred to use the same calculation methods for both cooperative and capitalist firms, and therefore to accept a rough evaluation of working capital requirement. To obtain it, we subtracted all debts except lessthan-one-year loans and banks overdrafts from the total circulating assets except liquid assets.

Columns 7 and 8 of Table 1 show the results for the working capital requirement. We must obviously compare them with the corresponding net working capital and this naturally leads us to the analysis of cash and term deposits.

\subsection{Cash and term deposits}

Since there is an accounting identity between the sums of the assets and liabilities, we can say that the difference between net working capital and working capital requirement is equal to the difference between the items of assets and liabilities not included in the calculation of the preceding magnitudes, that is, between liquid assets and short-term financial liabilities. This last difference is usually called the cash and term deposits and we can see in Table 1 that it is usually negative.

This means that SCOPs just like the other firms usually need short-term bank loans to finance part of their operating assets.

Although the cash and term deposits are more often negative on the capitalist than on the cooperative side (respectively in 11 and 9 of the 14 sectors), once divided by the turnover ${ }^{9}$, the situation becomes

8 For details, see J.L. Boulot et al. (1978, pp. 83-85).

9 J.L. Boulot et al. (1978, p. 87), among others, suggest that the cash and term deposits be expressed in relative terms. 
noticeably more difficult for SCOPs. This happens in 9 sectors (all these in the construction but for the electricity sector). Besides we have checked that SCOPs proportionally more frequently have recourse to discounting than the other firms. Yet, we might be surprised to see that SCOPs, in general very jealous of their autonomy, seem to be rather dependent on their banks. But we should also recall that their customary partner for short and middle-term transactions, is, in fact, the "Banque Française de Crédit Cooperatif", an institution belonging to the «Crédit Cooperatif "group whose aim is to promote the development of the whole French cooperative movement. It is easy to imagine that this institution is an enormous help of which SCOPs obviously do not hesitate to take advantage ${ }^{10}$.

\subsection{Rotation ratios}

We shall now try to understand why, despite a net working capital generally better than others, SCOPs usually have smaller cash and term deposits than other firms. In other words, we have to identify the factors responsible for greater working capital requirement among SCOPs. With that in mind, we shall isolate the main components of operating assets and non-financial short-term debts. Moreover, by introducing the time factor with rotation ratios, we shall study their respective rates of renewal. We hope we shall be able to estimate, on the one hand, the transformation rate of stocks into credits (through stock turnround) and the transformation rate of credits into liquidities (through the customers' average term of payment) and, on the other hand, the rate of suppliers' payments (through the average credit term granted by suppliers).

Although such ratios are to be used cautiously" ${ }^{n}$, we must, once again, make do with the only information available about SCOPs and capitalist firms. As far as stock turnround is concerned, for instance, we divide the turnover by the stocks rather than using sales estimated at cost price, which would be preferable. For the average term of accounts receivable $(R 3)$ and for the average term of accounts payable (R4), credits to customers and debts towards suppliers are recorded

10 SCOPs also use, to a large extent, the help of other financial institutions that most often belong to the social economy sector ( que Centrale des Cooperratives et Mutuellesw, etc.).

11 One has to be cautious when calculating and interpreting rotation ratios : see R. Lavaud and J. Albaut (1984, pp. 63-78) and J.L. Gillet et al. (1985, pp. 382-384). 
V.A.T. included whereas the denominator of those ratios (respectively the turnover and the firm's purchases) are recorded V.A.T. excluded.

Despite such limitations, the results obtained for R2, R3, R4 show several rather clear tendencies : the stock turnround is, in general, faster among SCOPs, except in the plumbing and carpentry sectors, where its weakness on the cooperative side fairly well explains the importance of working capital requirement. The difficulties with cash and term deposits encountered by SCOPs, though, can be more clearly understood with the two other ratios : on the one hand, the average term needed to receive payments from customers is usually longer for SCOPs and on the other hand, the credit granted by suppliers is usually shorter.

As far as the longer credit term that SCOPs grant to their customers is concerned, we could recall that worker-members have always been said to be "good producers" but *bad salesmen». Such a description may seem something of a caricature given the relatively small differences shown by the $\mathrm{R} 3$ ratio. Besides, accounts receivable is only one element of a firm's marketing policy. Nevertheless, we are faced with a typical feature of SCOPs which C. Vienney (1979) also highlighted : among the features of industries in which workers' cooperatives have developed most over the last hundred years, he notices a relationship between production conditions and marketing conditions to the advantage of the former ${ }^{12}$.

Another explanation, still related to the preceding one, is the proportionally bigger participation of SCOPs in public contracts, mostly in the construction sectors. Legal provisions have, for a long time, favoured such participation ${ }^{23}$ and public contracts procedures

12 C. Vienney $(1979$, p. 141) believes that this preference is linked to the firm's cooperative nature rather than to a deficient capacity and that SCOPs would rather produce well and try to sell rather than to produce what can be sold easily.

13 Among others, the public contracts code provides for :

A. a preference right : at equal cost or at equivalent offer, SCOPs are granted a preference right for what they offer or submit.

B. a lots reservation at the average price : when works, material and services are divided into lots of similar nature and consistency that concern a same profession and if each lot can be applied to a distinct market, the Administration must reserve, in a one out of four proportion, one or more lots that will be given, at the other lots average price, to SCOPs that have asked to benefit from this measure (See A. Antoni, 1980, pp. 85-87). 
probably correspond more to the SCOPs' preferences than do marketing strategies. It is a well-known fact, though, that it is unusual to receive rapid payment after fulfilling a contract with the public authorities; this is obviously a factor extending the average term of accounts receivable. Besides, this term is especially long in the public works sector for SCOPs as well as for other firms, and for telephone SCOPs i.e. mainly the AOIP'4, known to have worked, in 1979, up to $80 \%$ for governmental orders.

Now when we observe the average term of accounts payable (ratio R4), we notice a less general tendency than with the preceding ratio, but still we find that credit is almost always shorter for SCOPS in the construction sectors and in intellectual services. As far as architecture and technical studies are concerned, this is not at all surprising, for most SCOPs are so young that a certain distrust among suppliers can be understood. But as regards to construction, the fact is even more striking because it also represents the main results of a comparative analysis on liquidity carried out by J.L. Geron (1985) on 48 large SCOPs in the construction sector. Would this imply that SCOPs have a very poor image ? It might be possible that, the managers of a cooperative firm do not offer the same guarantees to the firm's partners, or a least not as explicitly, as a traditional manager would. Those partners would rather recognize one single person who carries final responsibility and who most often is the owner. But if this is so, we should have to explain why this shorter credit term cannot or can scarcely be found in the printing sector and in industry.

Another method would be to link the results obtained for ratios R3 and R4 i.e. suppliers would be more demanding towards SCOPs of the construction sectors than with other firms for they are more afraid that those have a higher chance of a cash and term deposits crisis because of their less strict policy towards their customers. But, here again, this is something which requires further thought. In any case, it introduces the notion of risk and thus the second half of our study.

\section{$2 \quad$ Financial risk}

A firm takes many types of risk expressed differently according to the different parties participating in the firm's activities. The usual method to clarify the problem consists in making a distinction bet-

14 The AOIP is the Workers Association in Precision Instruments, the most important SCOP in the 70's. 
ween the economic and the financial risk ${ }^{15}$.

Economic risk or operating risk can be defined as athe uncertainty or the dispersion of the future liquidities' flows, or the probability to have a net profit, before interests, smaller than $0 x^{16}$. It does not take into account the means to finance investment that will generate those liquidities' flows and it mostly depends on fixed operating charges that cannot be cut down in case of a recession.

The economic risk is undoubtedly high for most firms that we are studying here since the period we cover is marked by a deep crisis of the Western economies which strikes, among others, the whole construction sector. It could, nevertheless, be normal to think that the variations arising out of certain economic conditions can identically affect firms belonging to the same sectors and that it becomes more important, in a comparative perspective, to analyse financial risk ${ }^{17}$. Moreover, it is difficult to approach economic risk on a ratios basis ${ }^{18}$.

Financial risk arises when a firm finances its own business by making loans or by issuing bonds and must, at exact dates, redeem fixed amounts of money to satisfy its creditors. It, thus, comes from the fixity of these financial liabilities combined with economic risk, i.e. with the uncertainty of operating profits that should be covering these financial charges. Therefore, financial risk is added to operating risk and amplifies it.

Financial risk will be studied through a few ratios and will always present two different aspects. The first one will show the dangers threatening a firm (for example, insolvency or loss of its financial autonomy). The second one, on the contrary, will reflect the positive part played by the firm when it takes some risks. Being

15 Many more distinctions are still possible. See for example J.L. Boulot et al. (1978, ch. 4) and M. Levasseur and B. Piganiol (1981, ch. 1).

16 B. Solnik (1980, p. 110).

17 We could note that self-management theorists have most often modelized economic risk since they think uncertainty arises from some variables such as the product selling price or its level of demand. In fact though, worker-members met with a whole of risks and it seems more realistic to consider them as investors whose global investment (in labour and in capital) has an uncertain output because of financial risk as well as economic risk. In that sense, the analysis of financial risk can also be considered as a first approach of that global risk.

18 The sensitivity analysis models are more appropriate. See for example J.L. Boulot (1978, ch. 4 and 9). 
indebted, for instance, can, in some cases, increase the firm's profitability by a financial leverage effect ${ }^{19}$ or it can represent a growth factor for small and medium-sized businesses whose self-financing is not sufficient. Now, many doubt that workers in self-managed cooperatives are capable to accept enough risks ${ }^{20}$. We shall try, then, to test this hypothesis and therefore, to see if the ratios results tend to express a greater aversion towards risk on the cooperative side.

\subsection{Total debt degree}

The first ratio deals with total debt degree and to calculate it, we chose the classical loans and equity ratio. Therefore, the debt degree we obtained does not take into account all the financial risk determinants since it does not include, among others, interest rates and billspayable books. Generally speaking though, we can say that the higher the debt degree, the more the firm's financial risk increases.

By examining the results obtained for ratio $R 5$ (table 2), we realize that the total debt degree is smaller for SCOPs in nine sectors and is identical to the capitalist firms debt degree in two others. SCOPs of the public works, plumbing and the furniture industries are the only ones to appear comparatively more indebted.

We shall not, though, conclude by saying that financial risk is smaller on the cooperative side. In a SCOP, the equity to which we compare debts is, indeed, not the same as in a capitalist firm. In the latter, the shareholder who wants to sell out his capital shares must find a buyer, possibly through the stock market if the firm is quoted. This transaction obviously affects the structure of company ownership but not common stock level. In a SCOP, however, worker-members must one day or another, be repaid their shares when they leave the firm $^{21}$. And, even though the repayment is made at the shares' nominal value, the SCOP loses equity in the transaction. In other words, whereas the indivisible collective reserves of a SCOP constitute real equity, the common stock does not.

19 The financial leverage effect shows the influence of the financial structure on equity profitability. See J.P. Gillet et al. (1985, pp. 388-389).

20 Among them, J. Drèze (1976), G. Hawawini and P.A. Michel (1983) or J.P. Bonin (1985).

21 In fact, shares are repaid when members resign, are excluded or die. When worker-members retire, it does not necessarily mean that they lose their membership but the SCOP can, whenever it wants to, repay their shares. 
Another element has the opposite effect and tends to reduce financial risk in SCOPs : loans which are, in fact, replacing equity, can, to a large extent, be transformed into common stock after a certain time and, therefore, go into the denominator instead of the numerator in ratio $\mathrm{R5}$. It is not an automatic operation but those loans made with retained earnings linked to statutory commitments and deposited monthly on members' current accounts, are actually transformed into common stock as well as a large proportion of workers' profit-sharing. When one sees the great volume of these loans, this really is an advantage for SCOPs even though common stock has to be paid off eventually.

Other legal provisions also contribute to strengthen equity in SCOPs. First, we shall mention their obligation to have greater reserves than traditional firms : $15 \%$ of the profits have to be deposited in the legal reserve until the latter reaches the highest level of common stock that the SCOP has ever had (versus $5 \%$ of the profits to $10 \%$ of the common stock for other firms). Moreover, a development fund equal to a statutory or extraordinary reserve, must be endowed in a way fixed either by the statutes or decided yearly by the General Assembly ${ }^{22}$.

All those asymmetric elements make it difficult to figure out the meaning of ratio $\mathrm{R5}$ in terms of the attitudes SCOPs have towards risk. In order to do so, we shall wait until we have a more general idea about financial risk taken by SCOPs.

\subsection{Long-term debt degree}

To go deeper into our analysis, we shall now examine the longterm ${ }^{23}$ debt degree, excluding short-term debts from the preceding ratio. Interest charges linked to short-term debts can, indeed, be heavy but these debts have very little influence on the firm's financial risk : some of them do not imply any repayment because they are constantly being renewed as long as the policy regarding suppliers and other creditors does not change and as long as activity remains constant. Others, that vary with the level of activity, are repaid when

22 We can still point out that the law does not allow SCOPs to let their common stock be lower than half of the highest level ever reached since they have been created. About those legal provisions, see A. Antoni (1980, pp. 34$60)$.

23 In this case, the long-term includes the middle-term debt as well and thus, means a more-than-one-year term. 


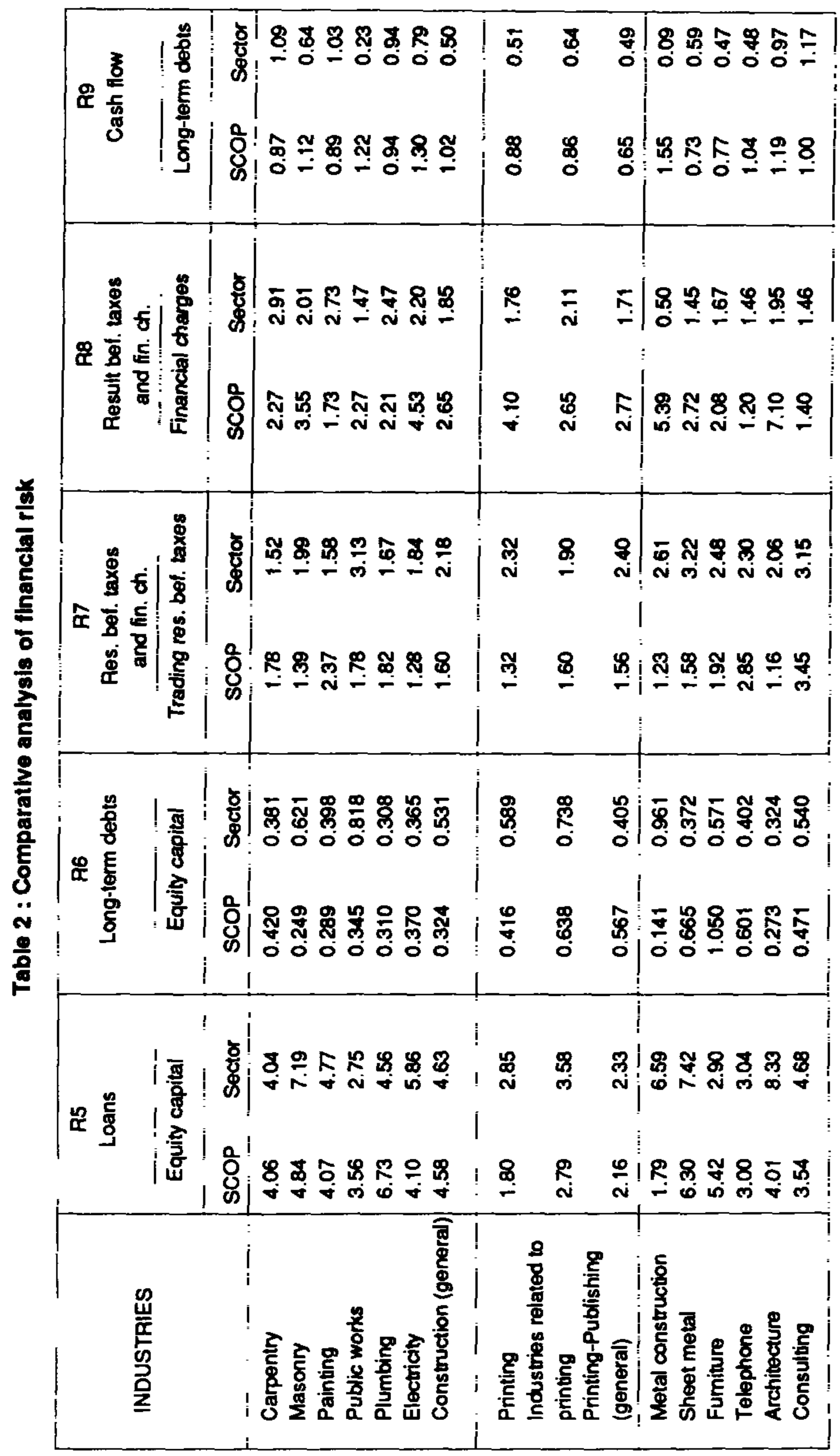


activity decreases, by the corresponding reduction of circulating assets and therefore do not create real problems except for interest charges to be paid.

With this second ratio, usually considered as an indicator of financial autonomy, we shall try, as far as possible, to take into account the very specific nature of loans replacing equity, which, because of their great volume, have quite truncated our estimation of the SCOPs' total debt. Therefore, we have to figure out, in each of the three categories of such loans, what proportion must be considered as long-term debt and what proportion assimilated to the equity since we know that it will be turned into nominal shares sooner of later.

First of all, members' current accounts almost only have deposits corresponding to the monthly retained earnings linked to statutory commitments. At the end of the year, these amounts become part of common stock and thus, must not be considered as debts but rather as future equity. Hence, we shall add them to common stock and to reserves.

As for the F.E.C. ${ }^{24}$ bonds and loans, they are only used by one out of five SCOPs and usually deal with very small amounts : the FEC interventions represent no more than six to eight million francs yearly. Moreover, part of these interventions take the form of subscriptions to common stock called "participatory loans". Yet, the FEC bonds and loans are still liabilities and, since they usually have a fiveyear term, we shall include up to $80 \%$ of them in more-than-one-year liabilities ${ }^{25}$.

Finally, we shall consider the case of participation accounts on which workers' shares in profits are deposited. It is, by far, the most important one because it involves very large amounts of money. Yet, no study has ever been made to calculate what proportion of the workers' participation in profits is transformed into common stock and what part is, in effect, paid to them. To figure it out approximately, we had to ask for the help of two experienced representatives of the SCOPs Confederation : according to the first one, almost three-quarters of worker-members' participation would become part of common stock but only a big half according to the second one. We, thus,

24 FEC (Confederal Expansion Fund) is a financial institution specific to the SCOPs general Confederation. It is mainly supplied with the SCOPs' subscriptions that corresponds to $0.1 \%$ of their turnover.

25 In other words, these shares are assumed to be regularly repaid over a five-year term. 
assume that approximately two-thirds of worker-members' participations are transformed into common stock. Both of them think that only $25 \%$ of non-member workers' participations are transformed into common stock. On the other hand, since participation accounts are blocked for a five-year term, we consider, as we did it above, that $20 \%$ of the participations that are not turned into common stock are repaid before the end of the year.

On the basis of that reasoning and of our knowledge of the $x$ proportion of worker-members in each sector, we then added to longterm and middle-term liabilities, already augmented of $4 / 5$ of the FEC bonds and loans, the following proportion of the workers' participations :

$$
0.80[0.33 x+0.75(1-x)]
$$

In parallel to that, we added to the equity, already augmented of members' current accounts, the proportion $[0.67 x+0.25(1-x)]$ of the same participations.

The results obtained with ratio $R 6$ so calculated remain rather favourable to SCOPs in terms of solvency and financial autonomy : their long-term debt degree is smaller in eight sectors and is practically identical to the sector average in two others. On the other hand, the financial risk estimated through long-term debt is comparatively fairly high for the SCOPs of three industrial sectors : the telephone, sheet metal and furniture industries. Since we found elsewhere an equity rotation exceptionally high for the last two ones as far as SCOPs are concerned, (see Defourny, 1990, p. 148), this tends to confirm our hypothesis : the equity of the sheet metal and furniture industries SCOPs is insufficient.

In the sheet metal industry, though, we had noticed a total debt degree smaller than the sector average. This probably means that they have not set off their lack of equity by an increased recourse to external loans, especially short-term loans. Hence, the financing was insufficient; this may explain our previous results, i.e. their very low capital-intensity and their bad performances in labor productivity and in profitability.

On the contrary, although SCOPs of the furniture industry had very little equity, it did not prevent them from having a very important debt degree: $R 5$ is almost twice higher on the cooperative side. This explains why in our previous study, the SCOPs of that particular sector stand among those having the best performance. And even though their lack of equity must be pointed out, their good behavior 
probably allows them to bear an important debt. We shall be able to test it with the following coverage ratios.

\subsection{Financial leverage degree and coverage ratios}

In a classical approach, financial leverage makes it possible to increase, under certain conditions, equity profitability by having recourse to debt. It may also be seen as an amplifier of the firm's financial risk as it is suggested by $H$. Ooghe and $C$. Van Wymeersch (1985). In that sense, they define the «financial leverage degree* as the elasticity of the trading result vis-à-vis the result before taxes and financial charges ${ }^{26}$. They show that this elasticity is, in fact, equal to these two results ratio :

financial leverage degree $=\frac{\text { result before taxes and financial charges }}{\text { trading result before taxes }}$

Our ratio R7 corresponds to this ratio and clearly shows the financial risk since it increases with the part of the result before taxes and financial charges which is absorbed by financial charges. We can check that with ratio $R 8$ as this ratio measures the financial charges coverage by the result before financial charges and taxes : the greater to one this ratio, the greater the firm's esafety blanket* is. The latter is used to reduce the impact of a result before financial charges decrease or of a debt increase.

Finally, one can also calculate another ratio in order to estimate the coverage of loans by cash-flow. Since financial risk is basically linked to long-term loans, we only take into account more-than-oneyear liabilities that we estimate just like for ratio $R 6$. We then divide the cash flow by the liabilities. This ratio R9 gives, thus, an idea of the theoretical repayment capacity of long-term liabilities ${ }^{27}$. This capacity can only be theoretical since no other allocation is considered for the firm's cash-flow.

Results for R7, R8, R9 are presented in Table 2. They show that financial risk is often smaller for SCOPs than for other firms. For instance, the financial leverage degree is really smaller and the financial charges coverage is undoubtedly better on the cooperative side, except in the carpentry, painting, plumbing, telephone indus-

26 For a given level of the result before financial charges and taxes.

27 This ratio is only meaningful when the cash-flow is positive but we have seen in Table 1 that it is always the case for the average firms we are studying. 
tries and the consulting sector. It is not at all surprising since the preceding results show, for SCOPs belonging to the first four sectors, a debt degree close to or higher than on the capitalist side, as well as a net profitability of assets and of equity that is not greater than the sector average. For SCOPs of the consulting sector, the relatively high debt mostly goes along with a very weak cash-flow, considering their size. Ratio R9 entirely confirms these results, except those of the telephone sector in which, because of a deep financial crisis, the AOIP cash-flow is swelled by exceptionally high amortizations.

\subsection{Do worker-members have an aversion for risk ?}

It should be possible to get an idea of the average attitude of worker-members towards risk by combining results of Table 2 and various other observations. The combination of smaller debt degrees and of an easier coverage of financial charges by the result (before financial charges and taxes) and of loans by the cash-flow could be considered as a necessary condition to prove the aversion of SCOPs towards risk. In this case indeed, there is, in principle, no difficulty at all in getting more indebted and if SCOPs don't do it, it may prove their aversion for risk.

We already know that this condition is not at all fulfilled by the SCOPs belonging to the five sectors we mentioned during our study of ratios $\mathrm{R} 7$ and $\mathrm{R8}$. In fact, the SCOPs of five other sectors are the only ones to show such features and a sixth one (public works) could be added if we favour long-term debt rather than total debt criterium. For three of them (masonry, printing and industries related to printing) though, we know from our previous study that SCOPs have a capital-labour ratio practically identical to the sector average and, given their size, a very good self-financing margin. Therefore, our deduction is that they invest normally but they prefer doing it with their own resources since their excellent profitability allows it. It still is possible that this preference is linked to an aversion for risk but even so, it is not at all harmful to the SCOPs performance.

In the metal construction industry and in architecture, SCOPs also fulfil the anecessary condition but their capital-intensity is much lower than the sector average. Shall we, then, conclude that they have a greater aversion for risk ? It is not at all certain for the cooperative groups studied here for the year 1979, are, to a large extent, very young firms. If, on the other hand, we take into account the whole decade in which the influence of young SCOPs is less felt, the capital-labour ratio on the cooperative side corresponds to the 
sector average and is even higher for the metal construction industry. Moreover, since we are dealing with industries in which the SCOPs profitability is excellent with, among others, a much greater cashflow despite an identical or smaller size than the other firms, we can still think that SCOPs would rather expand by self-financing ${ }^{28}$, even though their accumulation of productive capital is probably slower.

We are finally left with the public works sector. Here, SCOPs constantly show a more labour-intensive feature and they take much smaller financial risks than their capitalist counterparts. In this case, SCOPs could obviously get more indebted in spite of a rather limited equity, but they reject this solution and thus, give up more capitalintensive activities that they could take in charge with heavier equipment, within their sector. It is true that this option turns out to be rather successful but it suggest that many public works SCOPs confine themselves, even after their starting-up period, in activities requiring few investments and presenting little financial risk.

\section{Conclusion}

In brief, the available indicators do not show, for SCOPs as a whole, a greater risk aversion. We could find signs of possible aversion in less than half of the sectors. But even in these case, the fact that SCOPs take very little financial risk is usually linked to an excellent profitability and to a self-financing capacity that allows them to invest just like other firms though contracting fewer loans. In sectors where SCOPs remain a little more labour-intensive, it seems that, except for public works, the lower investment level is due to a limited profit earning capacity, to a relatively small cash-flow as well as to a lack of equity rather than to a greater fear to get indebted. Finally, if we consider that the analysis of the financial equilibrium was also a way to estimate risk, we shall recall that the SCOPs had lower cash and term deposits than their capitalist counterparts in most activities and it, thus, did not mean either a smaller risk on the cooperative side.

Yet, we would like to say again that it should be possible to define more adequately the question of worker-members' attitude towards risk. This problem remains practically unexplored at an empirical level and it needs much more research.

28 The equity rotation, equal or much smaller than the sector average, clearly proves this accumulation of their own financial means. 


\section{REFERENCES}

ANTONI A., 1980, La coopération ouvrière de production, Confédération générale des SCOP, Paris.

BONIN J.P., 1985, «Labor Management and Capital Maintenance : Investment Decisions in the Socialist Labor-Managed Firm*, in D.C. Jones and J. Svejnar, (eds.), Advances in the Economic Analysis of Participatory and Labor-managed Firms, vol. 1, pp. 55-70.

BONIN J.P. \& PUTTERMAN L., 1987, Economics of Cooperation and the Labor-Managed Economy, Harwood Academic Publishers.

BOULOT J.L., CRETAL J., JOLIVET J. \& KOSKAS S., 1978, L'analyse financière, Publi-Union, Paris.

COLASSE B., 1986, La rentabilité de l'entreprise, $3^{e}$ ed., Dunod, Paris.

CONSO P. \& LAVAUD R., 1984, Fonds de roulement et politique financière, $2^{e}$ ed., Dunod, Paris.

DEFOURNY J., (ed.), 1986, The Economic Performance of Self-Managed Firms. A Comparative Perspective, Special Issue of the Annals of Public and Cooperative Economy, vol. 57, no. 1.

DEFOURNY J., 1987, La performance économique comparée des coopératives de travailleurs. Le cas des SCOP françaises, Doctoral dissertation (2 volumes), Université of Liège.

DEFOURNY J., 1988, «Comparative Measures of Technical Efficiency for 500 French Workers' Cooperativesw. Forthcoming in D.C. Jones and J. Svejnar (eds.), Advances in the Economic Analysis of Participatory and Labor-Managed Firms, vol. 4, Jai Press.

DEFOURNY J., 1990, Démocratie coopérative et efficacité économique, De Boeck, Bruxelles and Editions Universitaires, Paris.

DREZE J.H., 1976, «Some Theory of Labor-Management and Participation», Econometrica, vol. 44, no. 6, pp. 1125-1139.

GERON J.-L., 1985, La performance économique des sociétés coopératives ouvrières de production en France, Mémoire, Université de Liège.

GILLET J.-P., GINSBURGH V., MICHEL P; \& KHROUZ F., 1985, Comptabilité, Office International de Librairie.

GLAIS M., 1984, Le diagnostic financier de l'entreprise, Economica, Paris. 
GUI B., 1985, «Limits to External Financing : A Model and an Application to Labor-Managed Firms*, in D.C. Jones and J. Svejnar (eds.), Advances in the Economic Analysis of Participatory and Labor-Managed Firms, vol. I, pp. 107-120.

HAWAWINI G. \& MICHEL P.A., 1983, "The Effect of Production Uncertainty on the Labor-Managed Firm×, Journal of Comparative Economics, vol. 7, pp. 25-42.

LAVAUD R. \& ALBAUT J., 1982, Ratios et gestion de l'entreprise, $3^{\mathrm{e}}$ ed., Paris, Dunod.

LEVASSEUR M. \& PIGANIOL B., 1981, Analyse et gestion financières de l'entreprise, Paris, Dalloz.

McCAIN R.A., 1977, «On the Optimum Financial Environment for Worker Cooperatives", Zeitschrift für Nationalökonomie, vol. 37, no. 3, pp. 355-384.

MEADE J.E., 1972, *The Theory of Labour-Managed Firms and of Profit Sharing”, Economic Journal, vol. 82, pp. 402-428.

MEUNIER H., de BAROLET F. \& BOULMER P., 1984, La trésorerie des entreprises, $2^{\circ}$ ed., Paris, Dunod.

OOGHE H. \& VAN WYMEERSCH, 1985, Traité d'analyse financière, 2 ed., Namur, Presses universitaires.

SCHLICHT E. \& VON WEIZSACKER C., 1977, «Risk Financing in Labor-Managed Economies, The Commitment Problem», Zeitschrift für die Gesamte Staatswissenschaft, Special issue on Profit Sharing, vol. 133, pp. 53-65.

UVALIC M., 1986, «The Investment Behaviour of a Labour-Managed Firm", Annals of Public and Cooperative Economy, vol. 57, no. 1, pp. 11-33.

VIENNEY C., 1979, "Coopératives ouvrières, pas si rétro que ça», Autrement, no. 20, pp. 138-146. 
Copyright of Annals of Public \& Cooperative Economics is the property of Blackwell Publishing Limited and its content may not be copied or emailed to multiple sites or posted to a listserv without the copyright holder's express written permission. However, users may print, download, or email articles for individual use. 